\title{
Research on the Application of Project-driven Teaching Mode on the Teaching of Multimedia Technology Curriculum in Colleges
}

\author{
Xubiao Wang \\ Puyang Vocational and Technical College, Puyang, Henan, 457000
}

Keywords: Project - Driven; Teaching Model; Vocational Education

\begin{abstract}
Application of the work process-oriented project-oriented teaching methods can be used to meet the requirements of higher vocational training for personnel. The use of project-based teaching is conducive to cultivating students' self-learning ability, teamwork ability and professional and technical ability. The project-oriented teaching mode is suitable for the training objectives and direction of higher vocational colleges.
\end{abstract}

\section{Introduction}

Project-driven teaching is driven by the project, the teacher completed the teaching task, and students complete the project through the knowledge point and complete the learning task. In the project-driven teaching model, students are in the real situation of the project, fully understand the basic requirements of each link, so as to cultivate the professional work and professional competence directly related to the future career in the real work situation. In the whole teaching, teachers to project-based, to guide students to complete the analysis, design, the scattered knowledge and operational skills organized together, students through specific projects to learn each knowledge points, to be integrated use, to establish engineering, Systematic concept, the knowledge from the perceptual knowledge rose to rational knowledge, to improve the enthusiasm of learning, enhance learning interest, positive, take the initiative to play, cultivate the team spirit of cooperation. The project is to complete the specific practice process, to achieve the ability to cultivate the job ability of teaching objectives.

\section{Teaching Content Reform}

In the higher vocational education, the introduction of project-driven teaching model is conducive to improving the traditional teaching mode, to meet the requirements of higher vocational colleges for personnel training, is conducive to cultivating students' self-learning ability, teamwork ability and professional and technical ability and other professional positions ability. The project-driven teaching model reform is suitable for the training objectives and direction of higher vocational colleges.

Here to computer multimedia technology courses "film and television animation production" as an example to explore the teaching content reform.

Curriculum Content Reform. (1) curriculum characteristics analysis

"Film and Television Animation" course is a cross-disciplinary courses, including graphic design, animation design, photography skills and other knowledge, a variety of software operation skills integrated application. "Film and television animation production" is the core of computer multimedia technology courses, but also an important part of the professional ability to cultivate 
students is the previous knowledge of the integration of the improvement of students' professional accomplishment has a very important role.

(2) to develop teaching objectives

In the development of the course of teaching objectives, the main consideration of two aspects: First, how to develop students' professional job capacity, including a variety of application software proficiency in the use of film and television animation production capacity, as well as the team's ability to cooperate. Second, in the completion of new knowledge learning, new skills are to improve at the same time, to achieve the integration of old and new knowledge. So in order to enable students to better grasp the skills, fully understand the actual process of the work process, should try to simulate the real experimental scene and learning environment.

(3) to build the curriculum system

"Film and television animation production" course learning is characterized by a large number of knowledge points into a variety of different projects. Students should continue to review the use of old knowledge in order to consolidate and improve new capabilities, to complete the integration of old and new knowledge links. In the construction of the curriculum system, it is to the action system based on the penetration of a variety of disciplinary system content.

Course Content Analysis. Project Name: Make the cat to catch the mouse animation.

Project content: collecting material, animation shooting, animation editing, synthetic output.

Course Design:

\begin{tabular}{|l|c|}
\hline professional class & Computer multimedia technology \\
\hline $\begin{array}{l}\text { Semester } \\
\text { arrangement }\end{array}$ & Fifth and sixth semester \\
\hline Weekly & $\begin{array}{l}\text { Curriculum theory knowledge has a certain reserve, but the lack of } \\
\text { experience in project production }\end{array}$ \\
\hline $\begin{array}{l}\text { Knowledge } \\
\text { preparation }\end{array}$ & $\begin{array}{l}\text { Teachers about the project production process and precautions, layout } \\
\text { need to review and preview the knowledge, and do the appropriate training. } \\
\text { Students are required to complete the project according to the teaching plan. }\end{array}$ \\
\hline $\begin{array}{l}\text { implementation } \\
\text { plan of }\end{array}$ & $\begin{array}{l}\text { The teaching process is progressing smoothly, the student knowledge } \\
\text { master system, formed a good job ability. }\end{array}$ \\
\hline $\begin{array}{l}\text { Analysis of } \\
\text { teaching situation }\end{array}$ & $\begin{array}{l}\text { Ideal } \\
\text { Analysis }\end{array}$ \\
\hline
\end{tabular}

The teaching model used in the above example is a conventional project-based teaching method. This method is widely used in the teaching of skills, is a successful project of teaching methods. The specific form of organization is: by the teacher to complete the project selection and formulation, and then the specific requirements of the project assigned to the students. By the student team to complete the study independently, throughout the teaching process, the teacher only to complete a certain degree of guidance work.

\section{Implementation and Implementation Methods}

\section{(1) item selection}

In the project of teaching, select the appropriate project is very important. The project should include the basic knowledge and basic skills of the course, to be able to mobilize the enthusiasm of students to explore the problem, so that students in the project context by the ability to collaborate and exchange capacity and other aspects of exercise. For the "website construction" course, after 
analysis, to determine the "e-commerce site design and production" as the course of the training project.

(2) project development team set up

After the project is identified, the class will be divided into a number of project development teams. When grouping, to complement the principle of comprehensive consideration of academic performance, learning ability, character temperament, the proportion of men and women and other factors, to make the group as much as possible balance, the number of groups according to the situation of the project to 5 to 8 people is appropriate Project development team set up a "project manager" one person, responsible for the implementation of this project task and completion.

(3) Project analysis

First, let the whole student, especially the project manager, clear the overall objectives of the project. In this case, through the project "e-commerce site design and production", so that students experience a small business site construction process, the integrated use of "website construction" in the knowledge and skills, and exercise teamwork ability.

Then, according to the overall goal of the project, the development team under the auspices of the project manager, the total project is broken down into a small project and fill out the project analysis form. The case analysis of this case is as follows:

\begin{tabular}{|c|c|c|c|}
\hline $\begin{array}{l}\text { comment } \\
\text { content }\end{array}$ & evaluation standard & $\begin{array}{l}\text { Total } \\
\text { Score }\end{array}$ & Score \\
\hline \multirow{5}{*}{$\begin{array}{l}\text { Commercial } \\
\left(25^{\prime}\right)\end{array}$} & $\begin{array}{l}\text { 1, product information is rich, the market demand analysis is } \\
\text { reasonable, accurate positioning }\end{array}$ & 5 & \\
\hline & $\begin{array}{l}\text { 2, establish the image of the site and brand, improve the site's } \\
\text { click-through rate. }\end{array}$ & 5 & \\
\hline & $\begin{array}{l}\text { 3, marketing and diverse ways to facilitate the needs of } \\
\text { customers }\end{array}$ & 5 & \\
\hline & $\begin{array}{l}\text { 4, promotional means rich, able to attract customers or potential } \\
\text { customers. }\end{array}$ & 5 & \\
\hline & $\begin{array}{l}\text { 5, follow the "service-oriented, customer first" purpose, to } \\
\text { provide multi-level customer service, including customer feedback } \\
\text { and information query. }\end{array}$ & 5 & \\
\hline \multirow{6}{*}{$\begin{array}{l}\text { technical } \\
\left(35^{\prime}\right)\end{array}$} & 1, skilled use of Dreamweaver & 5 & \\
\hline & $\begin{array}{l}\text { 2, with ASP programming capabilities, can produce dynamic } \\
\text { web pages. }\end{array}$ & 5 & \\
\hline & $\begin{array}{l}\text { 3, skilled use of Fireworks, Flash, Photoshop and other material } \\
\text { processing software }\end{array}$ & 5 & \\
\hline & $\begin{array}{l}\text { 4, skilled use of Access database management site, master the } \\
\text { basic SQL statement }\end{array}$ & 5 & \\
\hline & 5, can use IIS to publish and manage sites & 5 & \\
\hline & $\begin{array}{l}\text { 6, with a strong integrated web page processing capacity, } \\
\text { including fault tolerance }\end{array}$ & 5 & \\
\hline \multirow{3}{*}{$\begin{array}{l}\text { Informative } \\
\left(15^{\prime}\right)\end{array}$} & 1, can be timely collection of customer feedback & 5 & \\
\hline & 2, commodity information timely, reliable, rich & 5 & \\
\hline & 3, can provide convenient online service & 5 & \\
\hline \multirow{3}{*}{$\begin{array}{r}\text { artistry } \\
\left(25^{\prime}\right)\end{array}$} & 1, layout design beautiful, reasonable structure. & 5 & \\
\hline & 2, advertising planning creative, unique ideas, there is impact. & 5 & \\
\hline & 4, the majority of web content is original and unique ideas. & 5 & \\
\hline
\end{tabular}




\begin{tabular}{|l|l|l|l|}
\cline { 2 - 4 } & 5, the theme of prominent, rich and healthy and attractive. & 5 & \\
\hline total & 100 & \\
\hline
\end{tabular}

In the teaching, the works of the development teams can be displayed to all students and the students can freely express their views. The project development managers will score all the works according to the project evaluation feedback form. And then according to the feedback situation, the development team to make the appropriate changes to the work. This "evaluation feedback modification - re-evaluation feedback modification" can be repeated several times until the project objectives are met.

\section{References}

[1] Feng Jianying. "Project-driven teaching method" in the web design course application [J]. China Electronic Commerce, 2011 (3)

[2] He Jianmin, Guo Hongyan. "Case project-driven teaching method" in the computer teaching application [J]. Fujian Computer, 2010 (1)

[3] Xia Yongxiang, Shi Yunyu. Project-driven in the "multimedia technology" course experiment application [J]. Fujian Computer, 2016, (03): 86-87

[4] Zheng Miao. Application and Thinking of Project Teaching Method in Multimedia Technology Course Teaching [J]. Asia-Pacific Education, 2015, (33): $128+71$

[5] Li Zhaoxia, Li Zhaohui. Project-driven "multimedia technology and application" practice teaching [J]. Journal of Gansu Union University, 2010, (S1): 8-9 